\title{
Justiça do Trabalho: história, domínios e sujeitos
}

Labor Court: history, fields and characters

José Pacheco dos Santos Júnior

Fustiça do Trabalho: 70 anos de direitos

Beatriz Bulla et al.

São Paulo: Alameda, 2011. 262 p.

A Fustiça do Trabalho e sua história: os direitos dos trabalhadores no Brasil Ângela de Castro Gomes e Fernando Teixeira da Silva (orgs.) Campinas: Editora da Unicamp, 2013.528 p.

Exibindo sete décadas de existência, o Judiciário Trabalhista brasileiro entra no século XXI com o vigor de uma instituição que, pela importância e impacto que exerceu e exerce na regulamentação das relações trabalhistas no país,

José Pacheco dos Santos Júnior é mestrando em História Econômica na Universidade de São Paulo (USP) e pesquisador do Laboratório de História Social do Trabalho (LHIST/UESB) (josepsjunior@usp.br). Resenha recebida em 25 de junho e aprovada para publicação em 28 de julho de 2014. 


\section{José Pacheco dos Santos Júnior}

não escapa aos olhares atentos da comunidade intra e extra-acadêmica. Possibilitadas pelas renovações conceituais e metodológicas vislumbradas pela historiografia nas últimas quatro décadas, e matizadas pela potencialidade que emana da documentação (escrita e oral) da Justiça do Trabalho, duas obras coletivas vêm, num intervalo de dois anos, explorar a história dessa instituição instalada por Vargas à época do Estado Novo e inicialmente vinculada ao Poder Executivo: Fustiça do Trabalho: 70 anos de direitos, e $A$ Fustiça do Trabalho e sua história: os direitos dos trabalhadores no Brasil, objetos de discussão da presente resenha.

O primeiro livro, gestado sob os auspícios celebrantes dos exatos 70 anos da instalação da Justiça do Trabalho no país, é produção de quatro jornalistas especializados na área jurídica. Em Fustiça do Trabalho: 70 anos de direitos, salta aos olhos a bela proposta de articular uma obra que transite pelas sete décadas de atuação do Judiciário Trabalhista e pelas experiências de alguns de seus agentes, como juízes e advogados. Estruturado em três partes e detentor de uma última seção denominada "caderno de imagens", o conjunto de reportagens se apresenta ao público leitor como uma obra que persegue o objetivo de "rememorar fatos e acontecimentos históricos que conferiram à Justiça do Trabalho o título de 'Justiça Social do Brasil'"' (p.13). Para isso, a primeira parte, assinada por Mariana Ghirello (com reportagens de Daniella Dolme), expõe as principais marcas do cenário político-econômico brasileiro, desde a criação do Judiciário Trabalhista, na década de 1940, até os anos 2000. Na sequência, o cotidiano da Justiça do Trabalho é colocado em debate por William Maia (com reportagens de Thassio Borges). Nesta parte, ganham terreno tópicos como demandas, julgamento e execução dos processos, a informatização na Justiça do Trabalho, além das várias faces do cotidiano da advocacia trabalhista.

O ponto alto da obra se evidencia na reunião de entrevistas organizadas por Beatriz Bulla em parceria com o site Última Instância. Enfatizando as diversas trajetórias e concepções que alguns operadores do direito atribuem à Justiça do Trabalho, nesta terceira seção encontra-se uma importante entrevista com Arnaldo Süssekind, ministro do Tribunal Superior do Trabalho no período da ditadura militar, falecido um ano após a publicação da obra. Por outro lado, apesar dos belos insights expressados, o que deixa a desejar na publicação é a total ausência de referências bibliográficas e notas explicativas, além da rasa exploração do "caderno de imagens": seção que exibe inúmeras fotografias que, em sua maioria, estão desprovidas de fontes e autores, apenas munidas de breves legendas. Sopesando a ousada proposta aventada, com toda a licença que uma obra jornalística exige, o livro em questão se configura apenas como uma introdução básica, de caráter informativo, aos estudos sobre a história da Justiça do Trabalho.

Sob a coordenação de Ângela de Castro Gomes e Fernando Teixeira da Silva, historiadores que de longa data vêm se dedicando à História Social do Tra- 
balho e em particular à Justiça do Trabalho, a segunda coletânea opera uma cuidadosa análise, materializada em 11 textos que evidenciam os múltiplos traços da relação dos trabalhadores brasileiros com essa Justiça especial e com o mundo jurídico. Debruçado em histórias individuais e coletivas dos trabalhadores de diversos rincões do país, A Justiça do Trabalho e sua história: os direitos dos trabalhadores no Brasil reúne contribuições de pesquisadores de norte a sul do Brasil e de um canadense, todos querendo decifrar sujeitos, reclamações, cotidiano e as diversas estratégias de luta e negociação fomentadas na arena da Justiça do Trabalho.

Ao depositar suas expectativas e reclamações na Justiça do Trabalho, os trabalhadores legaram à posteridade registros que sinalizam uma cultura jurídica (e de classe) que extrapola as fronteiras do "legal institucionalizado" e contempla um delicado campo que compreende costumes e tradições na interpretação das leis, na definição de regras jurídicas, como também na afirmação de mecanismos legais para a resolução de conflitos. Visando interpretar essa seara, as contribuições desta obra distribuem-se em cinco eixos temáticos articulados através de seus propósitos em comum. Primeiramente, Clarice Speranza e Rinaldo José Varussa esmiúçam condições de trabalho e políticas de conciliação de classe no Sul do país em dois momentos distintos da história brasileira. Em um segundo momento, Antonio Luigi Negro e Edinaldo Souza, assim como Benito B. Schmidt, abordam as facetas do poder disciplinar, na Bahia (no caso dos dois primeiros autores) e no Rio Grande do Sul, recorte espacial de Schmidt. Em um denso e cuidadoso trabalho analítico, Fernando Teixeira da Silva explora a natureza do poder normativo nos domínios do TRT de São Paulo no "longo ano de 1963, que termina com o golpe civil-militar de 1964" (p.203), ao passo em que Larissa Rosa Corrêa examina a questão da Justiça do Trabalho e da política salarial entre 1964 e 1968.

Para além dos estudos que focam no eixo Rio/São Paulo e na força de trabalho industrial, ainda predominantes na historiografia brasileira sobre o labor, os capítulos de Antonio Montenegro e do canadense Frank Luce elegem como objeto de investigação as tramas dos trabalhadores rurais e magistrados do Nordeste brasileiro com o Judiciário Trabalhista, tratando de Pernambuco e da zona cacaueira da Bahia. Descortinando temas e privilegiando metodologias ainda pouco usuais nas análises acerca da Justiça do Trabalho, a quinta e última parte da coletânea convida o leitor a refletir sobre temas que compreendem, entre tantos outros discutidos, a regulamentação das relações de trabalho em Franca (SP), a terceirização e o trabalho análogo ao de escravo no Brasil contemporâneo, pontos e categorias dissecados respectivamente por Vinícius de Rezende, Magda Barros Biavashi e Ângela de Castro Gomes. 
Indispensável para a compreensão das lutas dos trabalhadores brasileiros na busca por direitos, e, num plano mais amplo, da própria edificação da cidadania no Brasil, A fustiça do Trabalho e sua história revela-se uma contribuição fulcral, ainda que seja uma pequena amostra dos estudos que hoje se dedicam à relação dos trabalhadores com esse ramo do Judiciário - estudos estes que, possibilitados pelo recente contato com os acervos dos tribunais trabalhistas, apresentam a dinâmica das tensões e experiências que até então estavam reservadas ao domínio da esfera privada do mundo do trabalho.

Se alguns dos grandes nomes do mundo jurídico ganham ênfase e voz na obra de Bulla et alii, na segunda coletânea, coordenada por Gomes e Silva, os trabalhadores (com suas disputas, acordos e conquistas) se veem historicizados num canal privilegiado. Todavia, numa época em que o Judiciário se encobre nas brumas do esquecimento, ao manter a política de descarte dos autos findos a partir de cinco anos de arquivamento, ${ }^{1}$ coletâneas como estas, aqui ligeiramente discutidas em face da limitada dimensão de uma resenha, têm todo o direito de se arvorar em obras-manifesto, mesmo que sem se enunciar enquanto tais.

Nota

1. BRASIL. Lei $n^{0} 7.627$, de 10 de novembro de 1987. Dispõe sobre a eliminação de autos findos nos órgãos da Justiça do Trabalho, e dá outras providências. 